\title{
Decolonising Israeli society? Resistance to Zionism as an educative
}

\section{practice}

\section{Elian Weizman, Kenyon Institute, Council for British Research in the Levant, Occupied Palestinian Territories}

\begin{abstract}
According to Samia Mehrez (1991: 255), a complete decolonisation process must include both the colonised and colonising societies. For the colonisers, decolonisation entails liberation from the hegemonic system of thought and from 'imperialist, racist perceptions, representations, and institutions'. Rooted in the conceptualisation of Israel as a settler colonial project, this paper aims to shed light on decolonisation attempts from within the (colonising) Israeli society. Here, resistance practices of groups of Jewish-Israeli anti-Zionists, in active support of the Palestinian struggle, entail a confrontation with the state but at the same time include another, long-term dimension: the formation of discourse and practice that challenge the Zionist consensus which thus function as an educative practice. This article aims to shed light on these activities and to conceptualise them as acts of 'critical pedagogy'. Indeed, their resistance teaches the Jewish-Israelis firstly about the reality of the oppression that Palestinians suffer. Secondly, and crucially, it reveals to the Jewish-Israelis the boundaries of permitted political activity and the possibility of overlooking and disregarding social conventions and legal norms. Most importantly, this type of activity (that is largely Palestinian-led and directed), symbolises the struggle against the boundaries and borders imposed by
\end{abstract}


This is the accepted version of an article published by Sage in Ethnicities Vol. 17 No. 4 pp.

574-597. Published version available from: https://doi.org/10.1177/1468796816666593

Accepted version downloaded from SOAS Research Online: http://eprints.soas.ac.uk/24986/

the state, aimed at separating Israelis from Palestinians and thus it constitutes a counter-hegemonic praxis.

\section{Keywords}

Decolonisation, Zionism, counter-hegemony, critical pedagogy, Israel/Palestine

\section{Introduction}

On 26 December 2003, the Israeli army shot, injuring two, unarmed demonstrators protesting against the construction of the wall Israel was building around the West Bank village of Masha. While similar incidents in which Palestinian inhabitants of the Occupied Palestinian Territories (OPT) are injured often go unnoticed in the media, this particular incident attracted media interest in Israel and internationally, since one of the injured demonstrators happened to be Gil Na'amati, a Jewish-Israeli activist. ${ }^{1}$ All reports mentioned the involvement of a group named 'Anarchists Against The Wall' (AATW) in the demonstration, but did not expand much on its identity, ideology or patterns of activity.

Writing in response to this same incident, Meron Benvenisti (2004), an Israeli essayist and historian, pointed to the uniqueness of this group. According to him, the demonstration was not aimed against the wall alone, but represents an ideological rebellion against the Israeli state and the sanctity of its laws: 
This is the accepted version of an article published by Sage in Ethnicities Vol. 17 No. 4 pp.

574-597. Published version available from: https://doi.org/10.1177/1468796816666593

Accepted version downloaded from SOAS Research Online: http://eprints.soas.ac.uk/24986/

There is no need to overestimate the importance of this group, which represents a marginal left-wing stream, with almost no influence. But one should also not underestimate the ideological and intellectual challenge that anarchists set before a society that attributes to the 'Jewish State' an absolute, sacred value, and worships 'laws' as though they embody, by their very legislation, supreme moral and social values. There is no democratic state in the world in which statism and submission to the law are the main principles of faith, as they are in Israel. [...]

After two generation of occupation, the precarious basis of the legality of the occupation power has been forgotten, and everyone takes the 'legality' or illegality [...] seriously. So it won't hurt to have a little bit of anarchy, that shouts out: 'the emperor is naked.'

In order to comprehend Benvenishti's critique, and to better understand the role of the AATW and other anti-Zionist activists within Israeli society, some reflections about the Israeli regime and Jewish-Israeli society are called for.

Following the rich literature on the historical development and the contemporary realities of the Zionist project and the Israeli state, Zionism is understood as a settler colonial movement, and accordingly, Israel as a settler colonial state (Salamanca et al., 2012; Shafir, 1989; Shafir and Peled, 2002; Weizman, 2013). In Israel, the (Jewish) ethno-national ideas of a community operate within a framework of liberal democratic 
This is the accepted version of an article published by Sage in Ethnicities Vol. 17 No. 4 pp.

574-597. Published version available from: https://doi.org/10.1177/1468796816666593

Accepted version downloaded from SOAS Research Online: http://eprints.soas.ac.uk/24986/

institutions. Indeed Israel defines itself as a 'Jewish and democratic' state and most Israeli Jews perceive themselves as living in a liberal democracy, and that the colonial and the religious-ethnic (Jewish) components at the basis of the regime do not negate the democratic character of the state. In fact, in Israel, nationalism is perceived as an essential component of the democratic regime (Azoulay and Ophir, 2012; Ram, 2011). Importantly, this is also how the majority of the international community perceives it.

The Zionist principle of Israel as a 'Jewish and democratic' state lays the foundation for the definition of the polity, its public culture, policies and the scope of protection of constitutional rights (Masri, 2013). Following the rich theoretical literature that conceptualises and problematises the concept of 'hegemony', and focuses on the delicate balance between consent and coercion in the creation of the people's 'common sense' (Anderson, 1976; Fontana, 2006; Gramsci, 1971, 1988; Lears, 1985; Mouffe, 1979), this paper treats Zionism, embodied in the idea that Israel is, and should remain, a Jewish and democratic state, as hegemonic amongst the Jewish-Israeli citizens.

Various apparatuses of the state play a fundamental role in structuring the nation as an ethnic group, as a historical narrative and political partnership. National identity and collective memory are structured and rooted in the ideological, bureaucratic and military spheres, in schools and households, in the work-place and in the army, thus becoming firmly established in the subjectivity of the people. Accordingly, the 
This is the accepted version of an article published by Sage in Ethnicities Vol. 17 No. 4 pp.

574-597. Published version available from: https://doi.org/10.1177/1468796816666593

Accepted version downloaded from SOAS Research Online: http://eprints.soas.ac.uk/24986/

commitment of the citizens to the state means a commitment to the existence of the Jewish state (Azoulay and Ophir, 2012). ${ }^{2}$ The perception of Israel as a democratic state despite its national-ethnic nature, receives further justification and legitimacy by the continuous overriding political concern with 'security'.

The employment of the term 'security' in Israel is pervasive and encompasses all spheres of life, and is being utilised at all times without the need to specify the reasons for its operations (Esmeir, 2004). Accordingly, the Israeli Security Agency (Shin Bet) is entrusted with maintaining the Jewish character of the state and acting against any subversive practices that undermine this definition (Khoury and Yoez, 2007). The consensus view in Jewish-Israeli society is that of continuous, existential danger (Sakana Kiyumit) to the very existence of the state. Israelis has internalised this feeling of danger and this expresses itself in the terminology with which the people use to speak about the conflict with the Arab states, understand Iran's nuclear programme, or perceive the Israeli occupation of the Palestinian territories. For what concerns us, this is also how anti-Zionist resistance practices, in which Jewish-Israelis are involved, are being treated. The perception of 'existential danger' has turned into an important component of Israeli 'security culture'. One of its manifestations is the ongoing legal 'state of emergency', activated in Israel from the day of its establishment until the present day. ${ }^{3}$ The 'state of emergency' allows the security apparatus to act in ways that 
This is the accepted version of an article published by Sage in Ethnicities Vol. 17 No. 4 pp.

574-597. Published version available from: https://doi.org/10.1177/1468796816666593

Accepted version downloaded from SOAS Research Online: http://eprints.soas.ac.uk/24986/

contradict the norms and laws that form the basis of democracy, without attracting public criticism. Indeed, 'security measures' and 'emergency regulations' are being endorsed and are seen as a necessary and inevitable part of the life in Israel (Pedhazur, 2003). Security concerns thus create a strong bond between the Jewish citizens and the regime. Hence, many scholars describe Israeli society as a 'conscripted society' (for example, see Kimmerling, 2001; Ophir and Peled, 2001). Similarly, Israel is described as a 'nation in arms'; thereby Jewish identity in Palestine was constructed mainly through the militarisation of society where the army served as an agent of development and integration (Ben-Eliezer, 1998; Kimmerling, 2001). 'Media in arms' is a term referring to the co-option and recruitment of the Israeli media on behalf of this 'nation in arms', thus curbing any significant criticism or alternative thinking in Israeli society (Pappé, 2011). All those examples reflect the unity of ends and means of the apparatuses of the state (and society) in the production of the Zionist common sense. These will also become apparent in the way anti-Zionist resistance is understood and treated in Israel.

Despite the debate on the essence of Israel's democracy, scholars agree that formal democratic institutions and processes do exist, including free elections, the separation of powers and the rule of law maintained by an independent judicial system. ${ }^{4}$ This point is crucial for the analysis of the forms of resistance presented here, as the 
This is the accepted version of an article published by Sage in Ethnicities Vol. 17 No. 4 pp.

574-597. Published version available from: https://doi.org/10.1177/1468796816666593

Accepted version downloaded from SOAS Research Online: http://eprints.soas.ac.uk/24986/

democratic structures enable forms of resistance that would not be available otherwise.

At the same time, the settler colonial drive and the ethno-national component in the state's definition are impeding its democratic structures. Moreover, resistance of the kinds discussed here puts a strain on the democratic structures, and pushes the state to rely more on its ethno-national component and thereby to lose its stance and legitimacy as 'the only democracy in the Middle East'. It is a strategy that exposes the contradictions between the state's Jewish and democratic pretensions, showing its willingness to suspend the one to defend the other, thereby revealing its coercive side.

Benvenisti's reflections presented above highlight the Jewish-Israeli common sense perception of the existing social order as sacred, to which obedience is the highest 'social test', and they are used here as a point of departure into a discussion regarding the strategy of resistance that chooses to subvert, overlook and disregard the existing norms, institutions and framework of the state. Given this very short introduction into the Israeli 'common sense' perception, I would argue that the resistance practices of anti-Zionist Jewish-Israelis, activities that disregard laws or military orders, and undermine, in their essence, the very idea of Zionism and its manifestations in current-day Israel, constitute an educational process, a Gramscian and Freirean counterhegemony and critical pedagogy. 
This is the accepted version of an article published by Sage in Ethnicities Vol. 17 No. 4 pp.

574-597. Published version available from: https://doi.org/10.1177/1468796816666593

Accepted version downloaded from SOAS Research Online: http://eprints.soas.ac.uk/24986/

\section{Counterhegemony and critical pedagogy}

Since Zionism, as an ideology and a system of power, is considered here as hegemonic in the Israeli state, anti-Zionist resistance is synonymous with the construction of a counterhegemonic project. Antonio Gramsci $(1977,1988)$ understood hegemony both as a form of rule - a way in which power is organised (in which terms he referred to it as the hegemony of the bourgeoisie), and as a strategy of struggle and an aim in itself (the establishment of the hegemony of the working class). In his discussion of hegemony as a field of struggle fought in the 'redoubts of civil society', Gramsci puts emphasis on the creation of a 'collective will', constructed of an ensemble of social groups with the aim of unifying the whole society around the political struggle. In order to achieve this, the disintegration of the bases of the existing hegemony, by disarticulating the ideological bloc of the existing intellectual position, is imperative. The precondition for this is the ability to rearticulate a new ideological system that will serve as cement for the new hegemonic bloc, incorporating national-popular ideological elements into a new hegemonic principle in a way that will represent the general interest.

Hegemony, therefore, must be understood as a process, an open-ended construction, and its forms can be partial, strong or weak, and include concealed 
This is the accepted version of an article published by Sage in Ethnicities Vol. 17 No. 4 pp.

574-597. Published version available from: https://doi.org/10.1177/1468796816666593

Accepted version downloaded from SOAS Research Online: http://eprints.soas.ac.uk/24986/

contradictions and fractures, as well as meanings and resources that are not fully controllable. Counterhegemony can therefore be explained as 'any practice that diminishes the number of sites of hegemonic articulation, reduces their range of application and makes them disarticulate and break up, thereby exposing [...] the growth of violence and coercion in the social...' (Chalcraft, 2007: 181).

Building counterhegemony, following the footsteps of Gramsci is, first and foremost, an educational process in which some agents within society are taking a pivotal role. Gramsci called those agents the organic intellectuals: the organisers, educators, and moral/intellectual leaders of a given social group or class that are distinguished by their function in directing the ideas and aspirations of the class to which they organically belong, rather than by their profession; and by their ability to achieve a unity of theory and practice, thinking and feeling (Gramsci, 1988: 5-23). Edward Said's treatment of what he terms the 'oppositional intellectual' follows similar lines. Said argues that the intellectual is 'someone whose place it is publicly to raise embarrassing questions, to confront orthodoxy and dogma (rather than to produce them)...' (Said, 1996: 11). Thus, simply put, the role of the contemporary intellectual is to speak 'truth to power'. In Said, the 'organic' connection is to a community of belonging, 'the nation', rather than class as Gramsci intended, a categorisation that is useful for our purposes. The role of the intellectual here is to critique the 'common 
This is the accepted version of an article published by Sage in Ethnicities Vol. 17 No. 4 pp.

574-597. Published version available from: https://doi.org/10.1177/1468796816666593

Accepted version downloaded from SOAS Research Online: http://eprints.soas.ac.uk/24986/

sense' perceptions that prevail in society, and to offer a new vision of the world instead. This includes a capacity for comprehending such a world, hence new vocabulary, knowledge and discourse. In so doing, intellectuals engage in a practice of education.

On the importance of the education in the struggle for liberation from oppression, the writing of the Brazilian educator Paulo Freire (2005) is instructive. What Freire terms critical pedagogy constitutes a revolutionary strategy that centres upon the transformative power of ideas, education, and the intellectuals. For Freire, pedagogy 'makes oppression and its causes objects of reflection [...], and from that reflection will come the[ir] necessary engagement in the struggle for their liberation.' (Freire, 2005: 48). Moreover, he insisted on the importance of critical thinking, as it 'discerns an indivisible solidarity between the world and the people and admits of no dichotomy between them - thinking which perceives reality as process, as transformation, rather than as a static entity - thinking which does not separate itself from action, but constantly immerses itself in temporality without fear of the risks involved.' (2005: 92). This approach, similarly to Gramsci's, is grounded in the philosophy of praxis: one that begins with life rather than theory, and constitutes acts that shape and change reality. Indeed, praxis is the combination of thought and action, a critical 'reflection and action upon the world in order to transform it' (2005: 51). Thus, it is the role of the organic intellectual to be the one who ignites, directs and disseminates the ideas that constitute a 
This is the accepted version of an article published by Sage in Ethnicities Vol. 17 No. 4 pp.

574-597. Published version available from: https://doi.org/10.1177/1468796816666593

Accepted version downloaded from SOAS Research Online: http://eprints.soas.ac.uk/24986/

new conception of the world in society that is crucial for the construction of counterhegemony (Hussein, 2015: 43).

Gramsci's and Freire's construction of counterhegemony is based upon a political theory in which the central protagonist is the intellectual/educator, and in which the politics of knowledge plays a central role in either enabling or disempowering social change. This insistence on the fundamental importance and primacy of the ideological struggle to social change means that the struggle should not be limited to consciousness raising, but must aim at consciousness transformation among the wider society. Critical pedagogy as the praxis of the intellectuals/educators' role is not limited to merely convincing their audience of their message, but also to build a new capacity for understanding it, to open new sensibilities, create a new language and with it a new type of a political subject (Freire, 2005; Gramsci, 1971: 325-332).

Critical pedagogy is thus strictly connected to the Gramscian concept of the war of position: the long process of ideological struggle, the process of transformation, disarticulation and re-articulation of existing ideological elements through which the new hegemonic bloc is cemented (Mouffe, 1979). This strategy aims at exposing the inherent weaknesses inside the hegemonic order that are an integral part of its character and internal contradictions. Its goal is to push towards the situation in which what was previously tolerated or considered as a legitimate disciplinary action within hegemony 
This is the accepted version of an article published by Sage in Ethnicities Vol. 17 No. 4 pp.

574-597. Published version available from: https://doi.org/10.1177/1468796816666593

Accepted version downloaded from SOAS Research Online: http://eprints.soas.ac.uk/24986/

will come to be understood as outright oppression, and the struggle itself as legitimate resistance to it (Noorani, 2007).

Here, it is about anti-Zionist resistance that pushes the Israeli state to defend its 'Jewish' character, at the expense of the 'democracy' component, thus exposing the contradiction inherent in this combination, and push the state to reveal its oppressive nature. This article presents and discusses the activities of two anti-Zionist 'groups' operating in Israel: the AATW, engaged in direct actions and the Boycott! Supporting the Palestinian Boycott, Divestments and Sanctions (BDS) Call from Within (in short: BFW). Appearing as visionaries of a new world view which is strictly oppositional to the one the Zionist common sense dictates, I would suggest that the AATW and the BFW should be understood and conceptualised as Gramscian/Saidian organic/oppositional intellectuals, and their resistance would be treated here as a practice of Freirean critical pedagogy. These activists, mostly originating from an affluent, Ashkenazi middle-class background, are creating a praxis of struggle, and a discourse which counters the one maintained by their hegemonic social/ethnic counterparts, and thus can be categorised as 'organic'. These two groups actually intersect and overlap, while most members of the AATW are also members of the BFW group, and vice versa. Indeed, these are both sides of the same struggle - from inside, on the ground and outside - appealing to 
This is the accepted version of an article published by Sage in Ethnicities Vol. 17 No. 4 pp.

574-597. Published version available from: https://doi.org/10.1177/1468796816666593

Accepted version downloaded from SOAS Research Online: http://eprints.soas.ac.uk/24986/

international public opinion.

\section{Anarchists against the wall}

AATW is a direct action group, inspired by the South African resistance movement, that was formed in April 2003 in response to the construction of the wall in the occupied West Bank. Ever since its formation, the group has participated in hundreds of demonstrations and direct actions against the wall specifically, and the occupation generally, in the West Bank as well as within Green Line Israel.

AATW activists join the Palestinian-led struggle against the occupation and the wall, coordinated through the Palestinian villages' local popular committees. This point is crucial, as one of AATW's activists explained, since the AATW activists are 'among the group of the over-privileged in this struggle for Palestinian rights, acting against a system that has at its very core the Zionist principle of differentiation' (interview with an activist, 30 July 2012). ${ }^{5}$ Accordingly, it is not a 'joint struggle' in the manner it is commonly described, but a Palestinian struggle which anti-Zionist Israeli (and international) activists join and lend their support to. ${ }^{6}$ The AATW mission, as it appears on the AATW Facebook page declares that:

It is the duty of Israeli citizens to resist immoral policies and actions carried out in our name. We believe that it is possible to do more than demonstrate inside Israel 
This is the accepted version of an article published by Sage in Ethnicities Vol. 17 No. 4 pp.

574-597. Published version available from: https://doi.org/10.1177/1468796816666593

Accepted version downloaded from SOAS Research Online: http://eprints.soas.ac.uk/24986/

or participate in humanitarian relief actions. Israeli apartheid and occupation are not going to end by themselves - they will end when they become ungovernable and unmanageable. It is time to physically oppose the bulldozers, the army and the occupation.

The group's nature and patterns of activity are revealed in conversations with its activists. The AATW is not an organisation, but rather, a loose group of people, working together in a non-hierarchical and horizontal mode of operation, with no central leadership. Decisions are taken together, in consultation within meetings or during operations, but always in response to the Palestinian needs and calls for support (interview with an activist, 24 December 2009). This is a vital principle: the popular resistance movement is first and foremost Palestinian, and 'the Israelis are a mere footnote in it' (Pollack as quoted in Hass, 2010).

AATW's presence as a group in demonstrations provides Palestinian civilians some degree of protection against army violence. The Israeli army's code of conduct is significantly different when Israelis are present and the tendency to resort to violence is significantly lower, even though still severe. The army tries to put an end to the Palestinian popular resistance using every form of repression, and to prevent Israeli activists from joining this struggle, using legal means. A military decree determines that 
This is the accepted version of an article published by Sage in Ethnicities Vol. 17 No. 4 pp.

574-597. Published version available from: https://doi.org/10.1177/1468796816666593

Accepted version downloaded from SOAS Research Online: http://eprints.soas.ac.uk/24986/

Israeli citizens are not allowed to enter the Palestinian Authority's controlled areas 'A' as marked in the Oslo Accords. ${ }^{7}$ Frequently, a military commander's order declares the area of the demonstrations a 'closed military zone' to which entry is denied. Since under the law of the occupation it is possible to indict people for participating in a demonstration, in the course of several years AATW activists have been arrested hundreds of times and dozens of indictments have been filed against them. In conversations with activists, many mentioned legal repression as an attempt by the state to crack down on the resistance. Indeed, the human and financial burden on the activists is severe, and activists complain about burnout, and some of them feel forced to leave the country in order to restore some sense of normalcy to their lives.

It is interesting to think about the patterns of activities of the AATW in light of Gramsci's counterhegemony and Freire's critical pedagogy, and to conceptualise these activists as organic intellectuals operating within Israeli society. In what follows, we will understand their strategies, and their effects. The most common strategy of resistance of the AATW is direct action. Direct action, as one of the activists explains, 'deals specifically and directly with the source of the problem, and not only with its representations, such as demonstrating in front of the Ministry of Defence or in the streets of Green Line Israel' (interview with an activist, 24 December 2009). Thus, direct action has an effect on the realities on the ground since 'we go and dismantle a 
This is the accepted version of an article published by Sage in Ethnicities Vol. 17 No. 4 pp.

574-597. Published version available from: https://doi.org/10.1177/1468796816666593

Accepted version downloaded from SOAS Research Online: http://eprints.soas.ac.uk/24986/

road block or a checkpoint and we open a road, clean a well or a cave' (interview with an activist, 22 December 2009). For example, in the area of the south of Mount Hebron, the outcomes of the AATW actions could be seen on the ground, where families came back to live in the caves and used the clean wells after the prolonged cleaning activity conducted there (interview with an activist, 16 August 2010). Direct action is a practical demand, and there is typically a shortage of people who are willing to take part in these activities, As another activist explains, 'what is always missing is the struggle and resistance on the ground. This is a pragmatic matter, this is what is needed, and this is what we [AATW] do' (interview with an activist, 4 January 2010).

Direct action is the embodiment of 'the move from the symbolic to the physical and material world. Even if actions can still be symbolic sometimes, they are nonetheless real' (interview with an activist, 24 December 2009). Indeed, there is always a spectrum and there is no one point between the symbolic or the real, every action embodies both, as one of the activists explains (interview, 4 January 2010) explains:

I think that a series of demonstrations in one village can help, if it means delaying the construction of the wall, and entails expenses and losses for the state and the army. Every day of delay in construction means losses of thousands of Shekels.... 
This is the accepted version of an article published by Sage in Ethnicities Vol. 17 No. 4 pp.

574-597. Published version available from: https://doi.org/10.1177/1468796816666593

Accepted version downloaded from SOAS Research Online: http://eprints.soas.ac.uk/24986/

You cannot break the whole wall in one day, but you can create an accumulative effect.

The activities of the AATW in the West Bank thus aim to shift the balance of power against the occupation, and to create constant resistance to it, in a way that makes life harder for the army.

Importantly, the resistance activities of the AATW lead to the exposure of the reality of oppression, separation and denial of rights that Palestinians suffer from to both a local and international public. This necessitates engagement in developing and maintaining relations with the media. Activists testify that this can be hard and frustrating work, but its importance is immense. The exposure in the media gives resistance coverage, and many people become aware of the realities the Palestinians are suffering from under Israeli military occupation, which are normally kept hidden by the Israeli state. While sporadic demonstrations or activities frequently go unnoticed, continuous demonstrations in a certain location tend to gain the media's attention and lead to the exposure of the whole project of the wall piece-by-piece. This message is directed also towards the outside, international media outlets that influence international public opinion. In the case of Israel, where international public opinion plays a role in the conflict, and Israel is struggling to maintain its positive image, this is an important 
This is the accepted version of an article published by Sage in Ethnicities Vol. 17 No. 4 pp.

574-597. Published version available from: https://doi.org/10.1177/1468796816666593

Accepted version downloaded from SOAS Research Online: http://eprints.soas.ac.uk/24986/

outcome to keep in mind (interview with an activist, 16 August 2010).

In a similar way, activities often aim to emphasise the absurdity of the situation on the ground. For example, building an 'outpost' in the vicinity of an existing settlement, as activists together with their Palestinian counterparts have done on several occasions (to name just two of these occasions: Levy, 2013; The Social TV, 2007), is an activity that is directed both to the international and the Israeli media, and made in order to point to the outright discriminative manner with which these issues are treated by the Israeli government and military.

The exposure of reality goes beyond an influence on public opinion, and infiltrates the legal sphere. The media coverage the struggle receives influences the parallel legal struggle that is conducted against the construction of different sections of the wall. The case of the Israeli Supreme Court 2007 judgment on the construction of the wall near the West Bank village of Bil'in is a striking example of this. ${ }^{8}$ Over there, the massive popular struggle uniting Palestinian, Israeli and international activists was caught up by the media, and became familiar all over the country. Michael Sfard, a human rights lawyer that handled the Bil'in case, recounted that once he arrived at the Supreme Court for the discussion of the case, Chief Justice Aaron Barak asked him, "what is so special about Bil'in that they demonstrate there for so long?" (interview with Michael Sfard, 30 December 2009). This, for Sfard, is an example of the way in which the popular 
This is the accepted version of an article published by Sage in Ethnicities Vol. 17 No. 4 pp.

574-597. Published version available from: https://doi.org/10.1177/1468796816666593

Accepted version downloaded from SOAS Research Online: http://eprints.soas.ac.uk/24986/

struggle had succeeded in making Bil'in's struggle unique, a fact that made the difference in the court's ruling:

There are 100 petitions against the construction of the wall. You have to make yours unique. And the popular struggle in Bil'in succeeded in doing so. A convention was created that 'this time we went too far' [in the decision to build the wall at that particular spot]. Therefore, I can say that the popular struggle goes hand in hand with the legal one.

Other actions inside Israel are meant to raise awareness of a policy or event that otherwise would remain hidden from the eyes of the public. For example, one of those actions is called 'Price Tag'. 'Price Tag' is the term used to describe actions taken by Jewish-Israeli extreme right-wing activists in the OPT, mainly from 2008 onwards against Palestinians and their property, but also towards the police, the military and, in some cases, towards radical anti-Zionist activists. These actions include physical attacks (most recently, in the summer of 2015, the burning of a house in the Palestinian village of Duma, where an 18-month-old baby and his parents were burnt to death), causing damage to property and mosques, spraying graffiti on holy sites, uprooting olive trees, burning fields, and assaults on police officers or military property, among others. 
This is the accepted version of an article published by Sage in Ethnicities Vol. 17 No. 4 pp.

574-597. Published version available from: https://doi.org/10.1177/1468796816666593

Accepted version downloaded from SOAS Research Online: http://eprints.soas.ac.uk/24986/

According to extreme right-wing activists, these are done in response to governmental decisions to dismantle 'illegal' constructions in outposts or to Palestinian attacks. In response to the right-wing 'Price Tag' actions, on April 2011, AATW activists printed price tags (labels) and attached them onto the original price tags in shops in Tel Aviv, Jerusalem and elsewhere, mainly in large fashion chains such as Zara and Mango. The idea was to disrupt the shoppers and the shopping experience and to raise awareness of the real meaning of the concept of a price tag: on the labels they added a short report on 'price tag' actions taken by right-wing activists (Sheizaf, 2011: 26). This form of protest was also meant to create a connection between the Israeli consumerist culture and the systems that enable the occupation of Palestinian territories. The link is found in the fact that Tel Aviv is perceived by most people (locals and foreigners) as a nice international city, with a shopping experience similar to one in London or New York, where one can shop in the same global brands such as Zara or H\&M, and where the same musical bands perform. This 'normality' enables and facilitates the feeling that life in Tel Aviv is normal, and that the oppression and violence are part of another, perhaps parallel, world. As Noam Sheizaf affirms: 'the [AATW] price tag action is spoiling the entertainment and shopping festivities of the Israeli routine for a moment.... The aim was achieved. The euphemism is broken, and we got another little reminder that after all, the situation here is not so normal' (2011: 26). 
This is the accepted version of an article published by Sage in Ethnicities Vol. 17 No. 4 pp.

574-597. Published version available from: https://doi.org/10.1177/1468796816666593

Accepted version downloaded from SOAS Research Online: http://eprints.soas.ac.uk/24986/

Another dimension of exposure/education surfaces if one examines AATW activities inside Green Line Israel, ones that are done rarely but considered 'according to the need' (interview with an activist, 4 January 2010). While most activists agree that these are not meant to convince the Israeli public, since they all affirmed that they gave up any hope for a change from within Israeli (Jewish) society, these actions are meant to be communicative in their disruptive nature, in their ability to create confusion and chaos. They are also assisting the group to form its community. For example, during Israel's escalation of violence on the Gaza Strip in 2008/9, known as 'Operation Cast Lead' several activists conducted direct action in Sde Dov military airport, located in the north of Tel Aviv, blocking with their bodies the entrance to the base, and attempting to prevent pilots from accessing the jet planes on their way to attack Gaza. They were wearing white masks and covered in fake blood, laying at the entrance to the base playing dead. Ayala, one of the protestors said that the protest was meant to 'show Israeli Air Force pilots the results of their actions in Gaza. [...] We came here to remind them of this' (Ilani, 2009). Other actions inside Israel are meant to raise awareness of a policy or event that otherwise would remain hidden from the eyes of the public, such as blocking roads in Tel Aviv with barbed wired from the separation wall (Haaretz Service, 2007).

Another educative/subversive dimension of their activity surfaces in the 
This is the accepted version of an article published by Sage in Ethnicities Vol. 17 No. 4 pp.

574-597. Published version available from: https://doi.org/10.1177/1468796816666593

Accepted version downloaded from SOAS Research Online: http://eprints.soas.ac.uk/24986/

examination of the nature of the activity. Apart from the purpose of the action itself, the very nature of the AATW struggle is subversive as it stands against the Israeli separatist policies that are meant to keep Jews and Palestinians apart. The struggle includes Jews and Palestinians, in a way that each side contributes what it can to the struggle, and increases each other's strength. The Palestinians are the initiators, the leaders, they bring the most 'manpower' to the struggle, and they are sacrificing much more, since they are the ones that suffer constantly from the direct oppression of the army, and the extensive arrests and harassments. The Israeli activists contribute in attracting media attention, gaining access to land and resources since they enjoy freedom of movement, but remain more as the 'silent partners' in the struggle (interview with an activist, 4 January 2010). Considering Israel's policies, this type of struggle is subversive by its very nature.

Moreover, these activities are educating the public about the fact that another reality is possible. Direct action and resistance on the ground symbolise the constant struggle against the boundaries and borders imposed by the state, which are aimed to separate Israelis from Palestinians, and borders that have become firm both physically and consciously for most Israelis. To this end, there are laws and decrees that prevent Israelis entering Palestinian cities, towns and villages in the OPT. The AATW's struggle is meant to dismantle existing distinctions, and at the same time, to point to 
This is the accepted version of an article published by Sage in Ethnicities Vol. 17 No. 4 pp.

574-597. Published version available from: https://doi.org/10.1177/1468796816666593

Accepted version downloaded from SOAS Research Online: http://eprints.soas.ac.uk/24986/

them and show them to the public (interview with an activist, 7 January 2010). In this way, demonstrating in the West Bank together with the local Palestinian population should be understood as a highly subversive activity since it is resisting Israel's attempt to create a strict separation between the two populations. The very act of the struggle together is undermining this separation, 'you cross checkpoints and borders in order to struggle together against the separation, in this sense, it is an anti-apartheid action' (interview with an activist, 24 December 2009). Therefore, there is a long-term educational goal here, which involves lessons about how to live together, and how to get out of the indoctrination in a way that will enable a different future for the people.

In sum, the AATW actions are meant to disrupt, to create chaos, to interfere and make the army spend its resources on dealing with the constant harassments that the demonstrations or actions are causing on the ground. Moreover, they are meant to raise awareness in the public, disrupt the daily routine, make people stop, think and realise the reality they live in.

AATW activists are, by definition, supporters of the Boycott, Divestment and Sanctions (BDS) call, promoted by the Palestinian civil society in 2005. It is an inside-outside simultaneous strategy that demands Israel stops its violation of Palestinian rights. It is therefore a continuation of the same strategy, using different tactics. 
This is the accepted version of an article published by Sage in Ethnicities Vol. 17 No. 4 pp.

574-597. Published version available from: https://doi.org/10.1177/1468796816666593

Accepted version downloaded from SOAS Research Online: http://eprints.soas.ac.uk/24986/

\section{Boycott! Supporting the Palestinian BDS call from within}

On 9 July 2005, the Palestinian civil society, a collection of Palestinian political parties, unions, associations, coalitions and organisations representing the three parts of the Palestinian people (Palestinian refugees, Palestinians under occupation and Palestinian citizens) issued a call for boycott, divestment and sanctions against Israel 'until it complies with international law and universal principles of human rights'. According to the call, these non-violent, punitive measures should be maintained until Israel meets its obligation to 'recognise the Palestinian people's inalienable right to self-determination and fully complies with the precepts of international law'. ${ }^{9}$ These include ending the occupation and colonisation; recognising the rights of the Palestinian citizens of Israel to full equality and respecting, protecting and promoting the right of return of the Palestinians refugees according to UN resolution 194.

The emergence of the BDS movement was inspired by the South African model of the international solidarity movement that waged a BDS campaign at the time of apartheid. Currently, the BDS is an international movement with growing number of people from around the world participating and collaborating at an increasing pace. But, whereas the Palestinian BDS call and movement has broad support within Palestinian 
This is the accepted version of an article published by Sage in Ethnicities Vol. 17 No. 4 pp.

574-597. Published version available from: https://doi.org/10.1177/1468796816666593

Accepted version downloaded from SOAS Research Online: http://eprints.soas.ac.uk/24986/

society, BFW is a marginal group in Israel in terms of its narrow membership and the inadmissibility of its message within Israel itself.

The involvement of Israeli citizens in boycott-related activities predates the formal Palestinian call of 2005. For many years, Israelis who chose to respect and promote the rights of the Palestinians have done so based on personal interaction and on a relatively small scale. Those few conscientious Israelis, as one of the activists explains, 'have also paid a personal price for speaking up and taking the side of the oppressed, and in trying to minimise such events in the future we decided to answer the 2005 Palestinian call for BDS as a group, allowing for those who wish to remain anonymous to still be active as well as allowing for like-minded individuals to join in' (interview with an activist, 30 July 2012). The 'Boycott! Supporting the Palestinian BDS Call from Within' group was finally officially formed in 2008. Its long name puts the emphasis on the group's role in supporting an existing and ongoing struggle rather than a creation of a new front of struggle. As the same activist explains: 'Our job is, therefore, not to come up with demands, but rather use our relative power to act as enablers for the needed change being among the privileged, the mode of struggle is not ours to dictate, but it is certainly our duty to participate' (interview with an activist, 30 July 2012).

The role of BFW is to support the international BDS call against Israel and legitimise it, to stress that it is directed towards Israeli governmental policies and Israeli 
This is the accepted version of an article published by Sage in Ethnicities Vol. 17 No. 4 pp.

574-597. Published version available from: https://doi.org/10.1177/1468796816666593

Accepted version downloaded from SOAS Research Online: http://eprints.soas.ac.uk/24986/

institutions and not Israeli individuals, and therefore that it is not anti-Semitic (as it is commonly portrayed by its opponents), but rather an anti-racist stance. As Tali Shapiro (2010), a member of BFW explains:

Israelis do have that unique role in the BDS movement $[\ldots]$ one of our roles is to 'kosher stamp' the movement, but that's hardly our only role, and we're not the first in history to hold this status. Whites did it in South Africa, in the US, Christian Germans in Nazi Germany, veterans do it in the anti-war movement [...]. They can choose to be a tool, or they can choose to take an active, thinking part. [...] We commit much of our time, resources and energy, and we do it knowing the consequences. We initiate and we join - that is what activists do.

The stated goals of the group are therefore to promote and support the Palestinian BDS call, and to act inside and outside Israel to raise awareness and encourage support for BDS. Until today, around 300 Israeli citizens and residents have signed the call. It is a very small minority group, but considering the BDS movement as a whole, its potential danger for the Israeli state and the effects of its activity are tremendous.

Support of BDS is an act of resistance that consists of the call to the world to put pressure on Israel to radically change its policies and to respect international law and human rights in regard to Palestinian rights of self-determination, freedom and equality 
This is the accepted version of an article published by Sage in Ethnicities Vol. 17 No. 4 pp.

574-597. Published version available from: https://doi.org/10.1177/1468796816666593

Accepted version downloaded from SOAS Research Online: http://eprints.soas.ac.uk/24986/

in Palestine. The main idea behind the BDS campaign is that Israelis will only be convinced to push their government to change its policies if the costs of maintaining the current situation become too high. It is an offensive-initiative act of resistance, rather than a defensive-responsive one like direct action. As Udi Aloni (2010) explains: 'BDS action is a life saving antidote to violence. It is an action of solidarity, partnership and joint progress. BDS action serves to preempt in a non-violent manner, justified violent resistance aimed at attaining the same goals of justice, peace and equality.' Following this line of thought, there is a clear educational message to the BDS campaign, and accordingly, the Gramscian framework of analysis suggested above would assist in the investigation of the patterns of resistance and the effects of this resistance on Israeli society.

One important role Israelis assume in the campaign is to do research into the corporations and institutions supporting and legitimising Israel's occupation, in coordination with the global campaign and the Palestinian BDS National Committee (BNC). This work is being carried out by 'Who Profits,' an investigation conducted by activists of the Coalition of Women for Peace, an Israeli feminist organisation, dedicated to 'ending the Israeli occupation of the West Bank, Gaza and the Golan Heights and reaching a just peace in Israel/Palestine', that since 2009 has decided to actively support the BDS call. Their investigation aims at exposing companies and 
This is the accepted version of an article published by Sage in Ethnicities Vol. 17 No. 4 pp.

574-597. Published version available from: https://doi.org/10.1177/1468796816666593

Accepted version downloaded from SOAS Research Online: http://eprints.soas.ac.uk/24986/

corporations involved in the occupation, and to promote a change in public opinion and corporate policies. The information uncovered about corporations' involvement in the 1967 occupation of the West Bank, Gaza Strip and the Golan Heights is then used in order to increase pressure on foreign companies and corporations to apply sanctions and divest from those corporations. Many of Who Profits activists are among the members of BFW.

While the strategy of the BDS campaign is to bring about the severing of ties between Israel and the international community, the effects of the campaign can be felt already, in the fear of losing those ties and losing international legitimacy. Tali Shapiro (Kilroy, 2011) explains:

This pressure was instrumental in fighting the South African apartheid regime [...]. This doesn't mean BDS is the only action taken. People have been taking to the streets in a very organised and consistent manner for years: we write, we speak abroad. South Africans did all this as well. Just as evil doesn't substantially change through geography and time, neither do the ways to fight it effectively.

One of BFW's activists explained that the support for BDS also stems from the fact that activism (such as the AATW) is limited in its ability to bring about a change: 'In 
This is the accepted version of an article published by Sage in Ethnicities Vol. 17 No. 4 pp.

574-597. Published version available from: https://doi.org/10.1177/1468796816666593

Accepted version downloaded from SOAS Research Online: http://eprints.soas.ac.uk/24986/

regards to BDS, the positive thing is that the strength of the Zionists is limited. The solidarity movement is deciding the moves. After all, Zionists can't control British or French public opinion' (interview with an activist, 4 January 2010). Since this BFW activist is also a committed AATW activist, he understands that the two forms of resistance are intertwined and mutually benefit each other. BDS is more of a middle-class activism as it involves academics and professionals, and most of the work is done in front of a computer.

The BFW is therefore involved in 'counter-branding' Israel, advocacy and solidarity. 'Who Profits' aims to uncover and provide information about the economic dimension, which BFW uses in its appeals to the relevant individuals, companies or groups. The target is not the economy alone but also the cultural and academic spheres. The actual work consists of appeals to artists who intend to come and perform in Israel, pleading them to cancel their shows, to companies that are involved in projects in the OPT, to organisations and individuals who support the BDS, as a sign of solidarity and to fend off any accusation of anti-Semitism, and well as participating in talks in Israel and beyond, advocating the message of this strategy of resistance and its importance in the struggle for Palestinian rights.

The work of BFW is outward facing, and its activists do not engage directly with the domestic sphere. Indeed many activists admit that they lost their belief in the 
This is the accepted version of an article published by Sage in Ethnicities Vol. 17 No. 4 pp.

574-597. Published version available from: https://doi.org/10.1177/1468796816666593

Accepted version downloaded from SOAS Research Online: http://eprints.soas.ac.uk/24986/

attempt to address the moral conscience of Israeli society, and to trigger a change from within. This, in turn, has led to the understanding that only external pressure could disrupt and alter the lives of the people that are now living in relative comfort and detachment from the surrounding reality of occupation, oppression and discrimination of the Palestinians, and could make people understand that the situation is not sustainable and therefore needs to change. In this approach, the educational message becomes clear. In a conversation with another BFW activist, he claimed that his engagement entails at least a belief in the rationality of Israeli society, 'that the majority of people in the country still desire to live and maintain certain quality of life for themselves, and are not driven solely by national-fanaticism. This means that with pressure, things can change' (interview with an activist, 21 May 2011). It can be thus determined that the resistance of the BFW is an 'end of the game' strategy, telling society that it must pay a price if it continues to support the policies carried out by all elected governments, that of occupation, oppression and discrimination. In sum, BFW activists are involved in 'reframing' the debate about Israel/Palestine, exposing weaknesses in the Zionist hegemony, and thus creating a counterhegemonic discourse.

Another dimension of resistance/education surfaces here. Similarly to the AATW, if one considers the importance of interaction with Palestinians as having been, and continuing to be, crucial in the activists' internal education process as it contributes 
This is the accepted version of an article published by Sage in Ethnicities Vol. 17 No. 4 pp.

574-597. Published version available from: https://doi.org/10.1177/1468796816666593

Accepted version downloaded from SOAS Research Online: http://eprints.soas.ac.uk/24986/

to the activists' radicalisation and to the undermining of the Israeli separationist policies. But there are other issues related to this point. Tali Shapiro explains that gaining the trust of the Palestinians, enough to be welcomed into their safe spaces, is an indication of success, 'our voices can only become relevant if we manage to achieve the latter. Otherwise, we are still the oppressors, speaking from a place of privilege. It's only when we're radical enough to step out of the binary paradigm that we can truly become part of the movement; otherwise, all we do is to perpetuate oppression' (Kilroy, 2011). Eyal Sivan, a filmmaker and supporter of the boycott campaign explains, "we have to give a new sense to the notion of what it means to be in a common struggle. [...]. The official Israeli policy is about separation. We have to think, also, what it means to fight against separation' (Sivan and Hammad, 2011). These comments help us to understand that there is another, long-term educational goal here, which involves lessons about how to live together, how to get out of the indoctrination that people are brought up with, in a way that will enable a different future in the land. Indeed, it is the praxis of struggle that educated those who struggle about alternative possibilities of existence.

This is an essential point: as Freire reminded us, in the attempt of the oppressors to exit their position and join the struggle of the oppressed, 'they almost always bring with them the marks of their origin: their prejudices and their deformations, which 
This is the accepted version of an article published by Sage in Ethnicities Vol. 17 No. 4 pp.

574-597. Published version available from: https://doi.org/10.1177/1468796816666593

Accepted version downloaded from SOAS Research Online: http://eprints.soas.ac.uk/24986/

include a lack of confidence in the people's ability to think, to want, and to know' (Freire, 2005: 50). Hence, an act of true solidarity with the struggle of the oppressed necessitates a process of 'rebirth' and a constant self-examination: 'those who undergo it must take on a new form of existence; they can no longer remain as they were.' (2005: 61). Accordingly, the process of internal education is of outmost importance to the activists themselves.

The educational message also surfaces through the evaluation of the effects of their activity on the Zionist discourse and the way they manage to 'get under the skin' of the Israeli society. This can be done through the examination of the hegemonic backlash to their activities that serves as an indication for the efficacy of this type of resistance. The harsher the repression is, and the more severe the reactions, indicates that the state perceives these activities as potentially dangerous and harmful. It is important to remember at this point that hegemony constitutes a delicate balance between consent and coercion, with the latter to be kept under strict control and careful use, in order for it not to become direct domination that relies on force alone. Nevertheless, the role of coercion to control those who cannot be co-opted otherwise is important, and cannot be ignored. When the balance tips to the coercive end of hegemony, it risks losing its legitimacy and justification as a 'rule by consent'. This is a

process that the Israeli state undergoes. Additionally, these reactions embody a 
This is the accepted version of an article published by Sage in Ethnicities Vol. 17 No. 4 pp.

574-597. Published version available from: https://doi.org/10.1177/1468796816666593

Accepted version downloaded from SOAS Research Online: http://eprints.soas.ac.uk/24986/

discursive change within Israeli society, regarding its self-perception. While it cannot be attributed to the work of the BFW alone, the impact of the BDS movement inside Israel can be evaluated through an examination of the discourse of those in the centres of power in Israeli hegemony: the media, parliament and the economy.

Every year, the Israeli government and civil society organisations are investing resources in the attempt to counter the BDS movement-led 'delegitimation campaign' that is considered by the Israeli ministry of foreign affairs to be equal to the threats posed by Iran, Hizballah or Hamas (Israel Ministry of Foreign Affairs, 2010), and to concentrate its efforts in public diplomacy (Hasbara) ${ }^{10}$ activities. The Israeli media increasingly reports on boycott attempts and successes, and promotes public counter-campaigns to combat the 'BDS threat'. One of those is '\#LOVEISRAEL, telling the true story of Israel', led by Peri Holding Group and Mako, the online interface of the Israeli popular TV Channel 2, that offers to invest one million NIS in an idea that will be chosen to 'join the struggle on our image in the world. ${ }^{11}$ On July 2015, the Israeli economic daily, Calcalist, exposed a report already prepared by the Ministry of Finance in 2013, estimating the annual damage that would be caused to the Israeli economy by a total boycott at 40 billion NIS (Amsterdamski, 2015). On June 2015, the Israeli Prime Minister Benjamin Netanyahu has claimed in a special address, that boycott threats are directed at 'the very existence of the State of Israel, not on its policy' 
This is the accepted version of an article published by Sage in Ethnicities Vol. 17 No. 4 pp.

574-597. Published version available from: https://doi.org/10.1177/1468796816666593

Accepted version downloaded from SOAS Research Online: http://eprints.soas.ac.uk/24986/

(Nana10, 2015). These are only a few, albeit important, examples of a political discourse, recruited media, and the signalling of BDS as the 'threat' to the Zionist project, that almost all means become legitimate in the battle to combat it. This battle intensifies when the state is exercising its coercive forces to silence its critics using legal, and other, means.

The anti-boycott law that the Israeli parliament passed in 2011 presents one interesting example of this process (The Knesset, 2011). The law allows those who regard themselves to have been harmed by a boycott to sue the person/s responsible for compensation. ${ }^{12}$ The law came under severe criticism, for placing limitations on the freedom of expression. Thus, by enacting this law, Israel has damaged its reputation and eroded its legitimacy, both internally, at least amongst liberal circles, and internationally, where Israel struggles hard to maintain its positive liberal-democratic image. ${ }^{13}$ This controversial law was subsequently suspended, but finally approved by the Israeli Supreme Court on February 2014, with minor amendments. Certainly, attempts at repressing resistance, by legislative or other means, expose the weaknesses of hegemony and shake its delicate balance: resistance forces hegemony to resort to coercive means, such as legislation of this type which, in turn, erodes its consensual base and sources of legitimacy, which are both vital parts of its strength, locally and internationally, and exposes its repressive side. 
This is the accepted version of an article published by Sage in Ethnicities Vol. 17 No. 4 pp.

574-597. Published version available from: https://doi.org/10.1177/1468796816666593

Accepted version downloaded from SOAS Research Online: http://eprints.soas.ac.uk/24986/

Many of the activists (of both AATW and BFW) have been targeted by Israeli security forces, including 'friendly' questioning, interrogations and arrests, mainly in the cases of participation in direct actions and demonstrations in the OPT. However, it is important to underline the fact that (until this day) the Israeli state hesitates to exercise direct repression towards Jewish-Israeli activists. Activists argue that this is done in an attempt to keep their activity in a marginal position, and away from the eye of the media. Indeed, cases of imprisonment of Jewish-Israeli activists are very rare, especially when compared to the level of repression exercised on Palestinian political activity, first and foremost on Palestinian inhabitants in the OPT but also in regard to Palestinian citizens of Israel, where Israel commonly uses arrests as deterrence (Asali and Baker, 2010). The repression of protest activity by Palestinian citizens is tolerated and accepted by the Jewish-Israeli public as legitimate control over 'subversive activity' from the kind that is identified with Israel's enemies, and aims to undermine the very existence of the Jewish state. On the contrary, the repression of the protests of Jewish citizens, even if belongs to the same ideological frame, is still considered to be less legitimate in the public's opinion, and is therefore not widely used. This means that a space for activism does exist. At the same time, this space is tightly controlled by the state that regulates and maintains it under its supervision. In this way, it can also maintain the resistance in its marginal position. 
This is the accepted version of an article published by Sage in Ethnicities Vol. 17 No. 4 pp.

574-597. Published version available from: https://doi.org/10.1177/1468796816666593

Accepted version downloaded from SOAS Research Online: http://eprints.soas.ac.uk/24986/

Repression is not found in the realm of state institutions alone. After all, the strength of hegemony generates a coherence of interests and means between the political (state) and civil society, while the latter can step in to suppress forms of resistance that are perceived to threaten its integrity. Indeed, activists of the BFW face forms of repression exercised by civil society, though it is often backed by official state representatives. These sometimes stem from the work of resourceful NGOs that are dedicated to monitoring and tracing these kinds of activities and who have access to political power in the state; the most prominent among these are the 'Israel Academia Monitor' (IAM) and 'Im Tirzu'. While the former is engaged mainly with tracing and exposing academics who actively support the BDS campaign, the latter is dedicated to Hasbara activities in the campuses and to public campaigns, conventions and tours that include witch-hunts and campaign against academics, and organisations that they consider are not Zionist enough (or at all). Reports prepared by these organisations are occasionally discussed in parliamentary committees' meetings; thus they have an actual effect on the political decision-making process. $^{14}$

Academic members of BFW suffer from harassment and attempts to threaten their position in their workplace in Israeli academia. At times, they are summoned for 'talks' with the rector of their universities, in an attempt to constrain their activity and threaten their position in the university (interview with an activist, 7 January 2010). In 
This is the accepted version of an article published by Sage in Ethnicities Vol. 17 No. 4 pp.

574-597. Published version available from: https://doi.org/10.1177/1468796816666593

Accepted version downloaded from SOAS Research Online: http://eprints.soas.ac.uk/24986/

another extreme example, Neve Gordon, a lecturer from Ben Gurion University who published an article in 2009 in the Los Angeles Times determining that Israel is an apartheid state and therefore must be boycotted economically, culturally and politically, was denounced and urged to resign by the university's president, Professor Rivka Carmi (Benhorin, 2009).

Overall, one cannot underestimate the effect the BFW and the BDS campaign has on Israeli society and its political system, both discursively and practically. It is possible to detect a discursive change, both in Israeli society and internationally about Israel and its policies, more openly recognising Israel's democratic deficit and oppressive policies towards Palestinians, citizens and occupied population. Internally, the BDS campaign has two contradictory effects. While on the one hand it can lead to societal pressure on the government to change, or at least review, its policies, on the other hand, it creates a feeling of 'siege,' in which the international community is perceived as turning against 'Israel', 'Israelis' and sometimes, for utilitarian purposes against Jews, and therefore it is portrayed as anti-Semitic in nature. This, in turn, leads to an additional closure in Israeli society, and the entrenchment of its positions. The latter process is the dominant one in Israeli society. It leads to further repression and the use of coercion against these expressions of resistance. The statements, counter-campaigns and diplomatic efforts made by Israeli politicians, civil society 
This is the accepted version of an article published by Sage in Ethnicities Vol. 17 No. 4 pp.

574-597. Published version available from: https://doi.org/10.1177/1468796816666593

Accepted version downloaded from SOAS Research Online: http://eprints.soas.ac.uk/24986/

organisations and the media indicate that the BDS campaign is indeed effective. It is too early to assess the long-term effects and whether it will lead to a change of policies, but the hegemonic reaction, in terms of both legislation and counter-BDS activity reveals its threatening potential. This repression and rejection of its message, forms the proof of its function as practice of critical pedagogy, and its counterhegemonic potential.

\section{Resistance as educational practice}

Considering Benvenisti's comments presented at the beginning, resistance practices of the kinds examined above are unique in the State of Israel, where loyalty to the state gains a sacred place, together with the acceptance of the Zionist ideology. In this context, disdain, promotion of an anti-Zionist message, and direct confrontation with the state should be understood as a struggle for the construction of a counterhegemonic project that represents a different balance of political power. This process is undertaken by those within society who act as organic intellectuals, educating the public, willingly or not, about the reality, its consequences, and about the possibilities for constructing a different future.

Nevertheless, it is important to note one point. Despite the subversive nature of their resistance activities, mostly stemming from the undermining of the separation policies of the Israeli state, there is a paradox embedded in these practices. The fact that 
This is the accepted version of an article published by Sage in Ethnicities Vol. 17 No. 4 pp.

574-597. Published version available from: https://doi.org/10.1177/1468796816666593

Accepted version downloaded from SOAS Research Online: http://eprints.soas.ac.uk/24986/

activists of both groups are identifiable as Israeli Jews, and using their privilege to enhance their struggle, unwittingly produces the very fault-line that the state is striving to maintain, and the activists struggle to dismantle. This paradox embodies the very strength of hegemonic structures, and the ambivalent nature of resistance to them. ${ }^{15}$ However, this is not to detract from the significance or potential of this praxis, which is itself has an internal-educational role, as was previously highlighted.

I follow here Mandy Turner's use of the decolonisation approach in the analysis of anti-Zionist Jewish-Israeli groups, as it is indeed essential to discuss, analyse and conceptualise the resistance of these individuals and groups from within Israeli society who struggle against the system of power that governs their lives and others in their name (Turner, 2015). As Samia Mehrez explains, a complete decolonisation process is one that constitutes 'an act of confrontation with a hegemonic system of thought $[\ldots]$. As such, decolonization becomes the contestation of all dominant forms and structures, whether they be linguistic, discursive, or ideological $[\ldots]$ for both the colonized and the colonizer'. This decolonisation, for the colonisers, entails a process of liberation '[...] from imperialist, racist perceptions, representations, and institutions' (Mehrez, 1991: 258). This is indeed a long and sometimes painful process of learning, and the praxis of struggle serves as the educative method. 
This is the accepted version of an article published by Sage in Ethnicities Vol. 17 No. 4 pp.

574-597. Published version available from: https://doi.org/10.1177/1468796816666593

Accepted version downloaded from SOAS Research Online: http://eprints.soas.ac.uk/24986/

Hence, a complete decolonisation approach must include those from within the colonising society, however small and marginal a group they may be, together with the (greater role of the) colonised. Therefore, in the larger frame of resistance to Zionism and the Israeli state as its embodiment, Jewish-Israeli anti-Zionist activists must be included, and their patterns of resistance studied and conceptualised as a long process of learning and educating. The resistance practices of the AATW and the BFW group are telling in this regard, as in their modes of action, in their thinking and practice, they produce and disseminate knowledge, and, even if unwillingly and through their rejection, repression and persecution, educate the Israeli public about the alternative possibilities of existing. Here, it is worth mentioning that the decolonisation process, 'requires not the restoration of a historically continuous and allegedly pure pre-colonial heritage, but an imaginative creation of a new form of consciousness and way of life' (Nederveen and Parekh, 1995: 3). The decolonisation of imagination, a concept which is closely related to that of the creation of alternative hegemonic common sense, "is closely linked to structural change, at a level at which, no matter the seeming historical or cultural continuity, new types of legitimation and therefore, 'imagination' occur' (O'Callaghan, 1995: 22). This is a process that must begin in the minds of the few, and expand throughout society, a long and steady war of position.

\section{Notes}


This is the accepted version of an article published by Sage in Ethnicities Vol. 17 No. 4 pp.

574-597. Published version available from: https://doi.org/10.1177/1468796816666593

Accepted version downloaded from SOAS Research Online: http://eprints.soas.ac.uk/24986/

1. The incident was reported in the New York Times, the BBC, the Financial Times and the Jerusalem Post, among others.

2. Similar discussions can be found also in Bishara $(1993,1996)$.

3. In fact, the 'state of emergency' predated the state itself and was established by the British Mandatory Government in 1945.

4. Even critical accounts such as Azoulay and Ophir (2012) emphasise this point; see also Peled and Shafir (2002). Oren Yiftachel (2006) also maintains that Israel holds at least a formal procedural democracy while being an 'ethnocracy'. Ethnocracy, a term coined by Yiftachel, describes a system of rule that is constituted by and for a dominant ethnic group. In this regime, a separation exists between pseudo-democratic characteristics such as free elections, freedom of religion and freedoms of expression, and the structure that reflects clear ethnic discrimination such as immigration laws, land laws, divisions of capital and resources.

5. All interviews with activists have been anonymised. This was done in order to protect the identity of those activists in the event that involvement in such activism and the expression of such views might be subjected to greater repression.

6. The issue of the 'joint struggle' was at the centre of several debates among Israeli and Palestinian activists. See Linah Alsaafin's article in The Electronic Intifada from 10 July 2012; responses by Maath Musleh on Beyond Compromise on 12 July 2012, and Cecilia Dalla Negra's interview with Ronnie Barkan on The Electronic Intifada on 8 August 2012, among many others.

7. The Oslo II Accords, signed in September 1995, determined that the Palestinian Authority holds both civil and security control over areas ' $A$ ' that include all Palestinian cities in the West Bank.

8. On 4 September 2007, the Israeli Supreme Court ordered the state to alter the route of the 'separation fence' at Bil'in, following a judgment that rejected the government's argument that this route was chosen as necessary for security-military reasons, and thereby justify the current route that passes on Bil'in's lands (Yoaz and the New Agencies, 2007).

9. For the full Palestinian call for BDS see: http://www.bdsmovement.net/call 
This is the accepted version of an article published by Sage in Ethnicities Vol. 17 No. 4 pp.

574-597. Published version available from: https://doi.org/10.1177/1468796816666593

Accepted version downloaded from SOAS Research Online: http://eprints.soas.ac.uk/24986/

10. Hasbara, the Hebrew word for explaining, refers to efforts dedicated to advocate Israeli policies and the Israeli state around the world.

11. See the campaign on the Mako website at: http://www.mako.co.il/special-love-israel. A similar campaign was launched by other media platforms such as Yediot Ahronot, the most-read Israeli daily newspaper.

12. The full version of the law in Hebrew is available at: \{https://www.nevo.co.il/law_word/law14/law-2304.pdf $\}$ accessed 25 July 2015.

13. The law drew criticism from NGOs involved in the protection of civil and human rights in Israel. During the stages of the readings of the law, 53 NGOs submitted a joint petition to the Attorney General protesting what they defined as an attempt to silence criticism and legitimate protest through anti-democratic laws. In the process of its legislation, the Association for Civil Rights in Israel (ACRI) submitted a position paper to the Knesset's Committee of Constitution, Law and Justice highlighting that the boycott is a legitimate, legal and non-violent form of political activity aimed at change, protest and criticism. ACRI further stresses that, from the explanatory notes to the law, it becomes clear that it is directed towards specific boycott initiatives, those that have to do with the occupation. According to ACRI, such selectivity means posing limits on certain types of expression that the current political majority in the Knesset disapproves of, and as such it undermines Israeli democracy (see Gild Hayu and Yakir, 2010). The law was also subject to severe international condemnation, with the editorial of The New York Times arguing on 18 July 2011, 'Israel's reputation as a vibrant democracy has been seriously tarnished by a new law intended to stifle outspoken critics of its occupation of the West Bank'. Additionally, Amnesty International's Deputy Director for the Middle East and North Africa, Philip Luther said, 'despite proponents' claims to the contrary, this law is a blatant attempt to stifle peaceful dissent and campaigning by attacking the right to freedom of expression, which all governments must uphold' (Amnesty International, 2011).

14. As a response to reports submitted by Im Tirzu and IAM, the Minister of Education, Gideon Sa'ar promised to examine these claims that he described as of great significance. In addition, Sa'ar said he is determined to act against faculty members calling for the academic boycott of Israeli universities asserting, 'this thing is unacceptable' (see the report of Kashti, 2010). The Knesset Education Committee conducted a discussion around the topic of 'exclusion of Zionist positions in the academia' on 2 November 2010, to which members of both Im Tirzu and the Institute were invited, together with the heads of all Israeli universities. In the discussion, 
This is the accepted version of an article published by Sage in Ethnicities Vol. 17 No. 4 pp. 574-597. Published version available from: https://doi.org/10.1177/1468796816666593 Accepted version downloaded from SOAS Research Online: http://eprints.soas.ac.uk/24986/

remarks were made about the unacceptability of the fact that academics support the boycott calls against Israeli universities in which they work. In September 2012, following a recommendation by an international committee established to investigate the academic quality of Ben Gurion University's (BGU) Politics and Government Department, to revise some of its programmes and hire new staff, Israel's Council of Higher Education decided to close the department altogether, forbidding it to register new students as of the 2013-14 academic year, due to what was described as an anti-Zionist bias in the department (see the report of Nesher, 2012).

15. On the ambivalent nature of resistance, and the intentional use that Jewish Israeli activists make of their privilege in their solidarity actions in the Occupied West Bank, see Fiona Wright's fascinating analysis in her forthcoming book, An Ethics of Complicity: Solidarity and Dissent in Jewish Israeli Left Radical Activism. Indeed Wright argues that solidarity performed in this way entails complicity with the Israeli state regime.

\section{References}

Alsaafin L (2012) How obsession with "nonviolence" harms the Palestinian cause. The Electronic Intifada, 12 July. Available at: https://electronicintifada.net/content/how-obsession-nonviolence-harms-palestinian-cau se/11482 (accessed 13 July 2012).

Aloni U (2010) Why I Back Israel Sanctions. Ynetnews, 1 May. Available at: http://www.ynetnews.com/articles/0,7340,L-3829694,00.html (accessed 1 May 2010).

Amnesty International (2011) Israel Anti-Boycott Law an Attack on Freedom of Expression. Available at: http://www.amnesty.org/en/news-and-updates/israel-anti-boycott-law-attack-freedom-e xpression-2011-07-12 (accessed 14 February 2013).

Amsterdamski S (2015) The Full Boycott Report Exposed: A Complete Boycott on Israel will Cost the Market 40 Billion Shekels a Year. Calcalist, 7 July. Available at: http://www.calcalist.co.il/local/articles/0,7340,L-3663692,00.html (accessed 7 July 2015). [Hebrew]

Anderson P (1976) The Antinomies of Antonio Gramsci. New Left Review I(100): 5-78. 
This is the accepted version of an article published by Sage in Ethnicities Vol. 17 No. 4 pp. 574-597. Published version available from: https://doi.org/10.1177/1468796816666593 Accepted version downloaded from SOAS Research Online: http://eprints.soas.ac.uk/24986/

Asali R and Baker A (2010) Prohibited Protest: Law Enforcement Authorities Restrict the Freedom of Expression of Protestors Against the Military Offensive in Gaza. Adalah: Haifa.

Azoulay A and Ophir A (2012) The One State Condition: Occupation and Democracy in Israel/Palestine. Stanford: Stanford University Press.

Ben-Eliezer U (1998) The Making of Israeli Militarism. Bloomington: Indiana University Press.

Benhorin Y (2009) President of Ben Gurion University: Call for Boycott: Crossing a Red Line. Ynet, 2 September. Available at: http://www.ynet.co.il/articles/0,7340,L-3771227,00.html (accessed 15 February 2013) [Hebrew].

Benvenisti M (2004) A Little Bit of Anarchy Won't Hurt. In Haaretz English Edition, 1 January. Available at:

http://www.haaretz.com/beta/a-little-bit-of-anarchy-won-t-hurt-1.110369 (accessed 27 October 2011).

Bishara A (1993) On the Question on the Palestinian Minority in Israel. Teoria ve-bikoret [Theory and Criticism] 3: 203-21 [Hebrew].

Bishara A (1996) The Israeli Arab: Studies in a Torn Political Discourse. In: Barelu A and Ginosar P (eds) Tsiyonut: Pulmus Ben Zmaneynu [Zionism: A Contemporary Controversy]. Sde Boker: Ben Gurion University Publishing House [Hebrew].

Chalcraft J (2007) Counterhegemonic Effects: Weighing, Measuring, Petitions and Bureaucracy in Nineteenth-Century Egypt. In: Chalcraft JT and Noorani Y (eds). Counterhegemony in the Colony and Postcolony. Basingstoke: Palgrave Macmillan, pp. 179-203.

Dalla Negra C (2012) “I can't dictate methods of Palestinian struggle": Israeli boycott activist interviewed. The Electronic Intifada, 8 August. Available at: https://electronicintifada.net/content/i-cant-dictate-methods-palestinian-struggle-israeliboycott-activist-interviewed/11561 (accessed 12 August 2012).

Editorial (2011) Not Befitting a Democracy. The New York Times, 18 July. 
This is the accepted version of an article published by Sage in Ethnicities Vol. 17 No. 4 pp. 574-597. Published version available from: https://doi.org/10.1177/1468796816666593 Accepted version downloaded from SOAS Research Online: http://eprints.soas.ac.uk/24986/

Available at:

http://www.nytimes.com/2011/07/18/opinion/18mon2.html?_r=2\&ref=opinion\&

(accessed 15 February 2013).

Esmeir S (2004) Introduction: In the Name of Security. Adalah's Review 4: 2-9.

Freire P (2005) Pedagogy of the Oppressed. London: Continuum.

Fontana B (2006) State and Society: The Concept of Hegemony in Gramsci. In Haugaard M and Lentner H (eds). Hegemony and Power: Consensus and Coercion in Contemporary Politics. Oxford: Lexington Books.

Gild Hayu D and Yakir D (2010) Emdat ha-aguda be-inyan hatza't hok isur hatalat herem [Position Paper Submitted to the Committee of Constitution, Law and Justice: Boycott Prohibition Law 2010]. Available at: http://www.acri.org.il/he/?p=2577 (accessed 14 February 2013) [Hebrew].

Gramsci A (1971) Selections from the Prison Notebooks of Antonio Gramsci. Edited by Hoare Q and Nowell-Smith G. London: Lawrence and Wishart.

Gramsci A (1988) A Gramsci Reader: Selected Writings, 1916-1935. Edited by Forgacs D. London: Lawrence and Wishart.

Haaretz Service (2007) Leftist Activists Constructed a Separation Fence in a Tel Aviv Street. Haaretz, 2 February. Available at: http://www.haaretz.co.il/misc/1.1383222 (accessed 15 July 2015) [Hebrew].

Hass A (2010) Yonatan Pollack, Does Your Protest Influence Someone? Haaretz, 29 December. Available at: http://www.haaretz.co.il/hasite/spages/1206550.html (accessed 24 March 2011) [Hebrew]

Hussein C (2015) The Re-Emergence of the Single State Solution in Palestine/Israel London: Routledge.

Ilani O (2009) Anarchists' block entrance to IAF base in protest of Gaza strikes. Haaretz English Edition, 2 January. Avaliable at: http://www.haaretz.com/news/anarchists-block-entrance-to-iaf-base-in-protest-of-gaza-s trikes-1.267351 (accessed 15 July 2015). 
This is the accepted version of an article published by Sage in Ethnicities Vol. 17 No. 4 pp. 574-597. Published version available from: https://doi.org/10.1177/1468796816666593 Accepted version downloaded from SOAS Research Online: http://eprints.soas.ac.uk/24986/

Israel Ministry of Foreign Affairs (2010) Frequently Asked Question: The Campaign to Defame Israel. Available at:

http://mfa.gov.il/MFA/ForeignPolicy/FAQ/Pages/FAQ Attack Israeli Values.aspx (accessed 5 May 2011).

Kashti O (2010) Minister of Education Gideon Sa'ar: I Will Act Against Lecturers that are Calling for the Academic Boycott of Israel. Haaretz, 21 June. Available at:

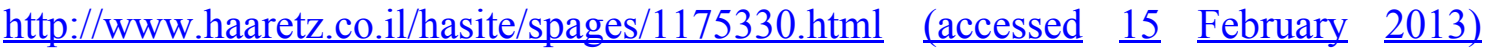
[Hebrew].

Khoury J and Yoez Y (2007) The Shin Bet: We Have the Right to Tap those Who Conduct Legal Activity to Change the Jewish Character of Israel. Haaretz, 20 May. Available at: http://www.haaretz.co.il/hasite/spages/861580.html (accessed 23 June 2012. [Hebrew]

Kilroy E (2011) Interview with Israeli BDS Activists Tali Shapiro: The Fear of International Isolation is Shifting the Discourse in Israel. Mondoweiss.net. Available at: http://mondoweiss.net/2011/03/interview-with-israeli-bds-activist-tali-shapiro-the-fearof-international-isolation-is-shifting-the-discourse-in-israel.html

Kimmerling B (2001) The Invention and Decline of Israeliness: State, Society, and the Military. Berkeley: University of California Press.

The Knesset (2011) Law for Prevention of Damage to the State of Israel through Boycott-2011. Sefer ha-hukim [The Legal Code]. Available at: https://www.nevo.co.il/law_word/law14/law-2304.pdf (accessed 13 March 2012) [Hebrew].

Lears J (1985) The Concept of Cultural Hegemony: Problems and Possibilities. The American Historical Review 90: 567-93.

Levy, E (2013) IDF foils construction of new Palestinian outpost. Ynetnews, 2 September. Available at: http://www.ynetnews.com/articles/0,7340,L-4342810,00.html (accessed 8 May 2016).

Masri, M (2013) Love suspended: Demography, Comparatice Law and Palestinian Couples in the Israeli Supreme Court. Social and Legal Studies 22 (3): 309-334. 
This is the accepted version of an article published by Sage in Ethnicities Vol. 17 No. 4 pp. 574-597. Published version available from: https://doi.org/10.1177/1468796816666593 Accepted version downloaded from SOAS Research Online: http://eprints.soas.ac.uk/24986/

Mehrez S (1991) The Subversive Poetics of Radical Bilingualism: Postcolonial Francophone North African Literature. In: LaCapra D (ed) The Bounds of Race: Perspectives on Hegemony and Resistance. Ithaca, Cornell University Press, pp. 255-277.

Mouffe C (1979) Hegemony and Ideology in Gramsci. In: Mouffe C (ed) Gramsci and Marxist Theory. London: Routledge \& Kegan Paul Ltd.

Musleh M (2012) The Legitimate Criticisms of the Popular Resistance. Beyond Compromise, 12 July. Available at: http://beyondcompromise.com/2012/07/12/the-legitimate-criticisms-of-the-popularresist ance/ (accessed 13 July 2012).

Nana10 online (2015) Senior Official: "We Do Not Have the Tools to Deal with the Boycott Threat"'. Nana10, 5 June. Available at: http://news.nana10.co.i1/Article/?ArticleID $=1130308$ (accessed 7 July 2015).

Nederveen P and Parekh B (1995) The decolonization of imagination: culture, knowledge and power. In: Nederveen P and Parekh B (eds) The Decolonization of Imagination: Culture, Knowledge and Power. London: Zed Books.

Nesher T (2012) Against Recommendations, the Council of Higher Education Recommends to Close a Ben Gurion University's Department. Haaretz, 11 September. Available at: http://www.haaretz.co.il/news/education/1.1821613 (accessed 15 February 2013) [Hebrew].

Noorani Y (2007) Redefining Resistance: Counterhegemony, the Repressive Hypothesis and the Case of Arabic Modernism. In: Chalcraft JT and Noorani Y (eds)

Counterhegemony in the Colony and Postcolony. Basingstoke: Palgrave Macmillan, pp. 75-99.

Ophir A and Peled Y, eds (2001) Yisrael: mi-hevra meguyeset le-hevra ezrahit? [Israel: From Conscripted Society to a Civil Society?]. Jerusalem: Van Leer Institute [Hebrew].

O'Callaghan M (1995) Continuities in Imagination. In Nederveen P and Parekh B (eds) The Decolonization of Imagination: Culture, Knowledge and Power. London: Zed Books. 
This is the accepted version of an article published by Sage in Ethnicities Vol. 17 No. 4 pp. 574-597. Published version available from: https://doi.org/10.1177/1468796816666593 Accepted version downloaded from SOAS Research Online: http://eprints.soas.ac.uk/24986/

Pappé I (2011) The Forgotten Palestinians: A History of the Palestinians in Israel. New Haven: Yale University Press.

Pedhazur R (2003) The Israeli 'Security Culture' - its Roots and Influences on the Israeli Democracy. Politica [Politics] 10: 87-117. [Hebrew]

Ram U (2011) Israeli Nationalism: Social Conflicts and the Politics of Knowledge. New York: Routledge.

Salamanca, O, Qato M, Rabie K et al (2012) Special Issue: Past is Present: Settler Colonialism in Palestine. Settler Colonial Studies 2(1).

Said, E W (1996) Representations of the Intellectual. New York: Vintage Books.

Shafir, G (1989) Land, Labor and the Origins of the Israeli-Palestinian Conflict 1882-1914. London: University of California Press.

Shafir G and Peled Y (2002) Being Israeli: The Dynamics of Multiple Citizenship. Cambridge: Cambridge University Press.

Shapiro T (2010) Law of Boycott Prohibition. Pulse. Available at: http://pulsemedia.org/2010/06/24/law-of-boycott-prohibition/ (accessed 30 March 2011).

Sheizaf N (2011) Instruction Manual. Time Out Tel Aviv, 4-11 April: 26.

Sivan E and Hammad S (2011) Q\&A: Eyal Sivan Speaks to Al Jazeera. Al Jazeera English, 22 May. Available at:

http://english.aljazeera.net/indepth/features/2011/05/201152285514634348.html (accessed 30 June 2011).

The Social TV (2007) 'First Candle' outpost in E1. Available at: http://tv.social.org.il/politics/2007/12/24/stv-e1-haner-harishon-8-12-07 (accessed 8 May 2016).

Turner M (2015) Creating a counterhegemonic praxis: Israeli activists and the challenge to Zionism. Conflict, Security and Development 15(5): 549-574. 
This is the accepted version of an article published by Sage in Ethnicities Vol. 17 No. 4 pp. 574-597. Published version available from: https://doi.org/10.1177/1468796816666593 Accepted version downloaded from SOAS Research Online: http://eprints.soas.ac.uk/24986/

Weizman E (2013) Hegemony, Law Resistance: Struggles Against Zionism in the State of Israel. PhD Thesis, University of London.

Wright F (Forthcoming) An Ethics of Complicity: Solidarity and Dissent in Jewish Israeli Left Radical Activism.

Yiftachel O (2006) Ethnocracy: Land and Identity Politics in Israel/Palestine. Philadelphia: University of Pennsylvania Press.

Yoaz Y and the New Agencies (2007) Court orders state to alter West Bank separation fence route at Bil'in. Haaretz English Edition, 4 September. Available at:

http://www.haaretz.com/news/court-orders-state-to-alter-west-bank-separation-fence-ro ute-at-bil-in-1.228761 (accessed 15 July 2015). 